\title{
Lymphoid aggregates in bone marrow: study of eventual outcome
}

\author{
B E FAULKNER-JONES, A J HOWIE, B J BOUGHTON, * I M FRANKLIN †
}

From the Departments of Pathology and ${ }^{*}$ Haematology, The Medical School, University of Birmingham, and the †Department of Haematology, Queen Elizabeth Hospital, Birmingham

SUMMARY The practical importance of finding a morphologically benign lymphoid aggregate in the bone marrow of patients without known lymphoproliferative disease was assessed in 786 consecutive patients who had had 951 iliac crest bone marrow biopsies performed. Of these, 430 patients known to have lymphoproliferative disease at the time of biopsy were excluded. Of 356 patients, 86 (aggregate group) had at least one lymphoid aggregate in their biopsy specimen ( 82 morphologically benign, three suspicious, and one malignant). Another 86 patients without aggregates (control group) were matched by age and sex. Both groups were followed up until death, or for a mean of 21.9 and 22.9 months, respectively, to assess their outcome. Eighteen $(22 \%)$ of the 82 patients with morphologically benign lymphoid aggregates were later proved to have lymphoproliferative disease compared with none of the 86 control patients. Another 12 patients in the aggregate group and seven in the control group were suspected of having a lymphoproliferative disease on clinical grounds, so that altogether $30(37 \%)$ and seven $(8 \%)$, respectively, developed confirmed or suspected lymphoproliferative disease. In both cases the differences were highly significant $(p<0.001)$.

It is suggested that lymphoid aggregates in clinical biopsy material may not be a physiological finding and should alert pathologists or haematologists to the possibility of lymphoproliferative disease.

Nodules and infiltrates of lymphocytes have been reported to occur in between $1 \%$ and $62 \%$ of human bone marrow specimens. The prevalence is influenced by the age and sex of the patient, the site and method of biopsy, and whether clinical or necropsy material is studied. ${ }^{1-4}$ In this report lymphoid nodules and infiltrates will be referred to collectively as lymphoid aggregates.

Benign and malignant aggregates have been distinguished on the basis of their morphology and cytology using light microscopy and conventional staining techniques. ${ }^{1-4}$ Immunohistological methods have also been used. ${ }^{356}$ Morphologically malignant lymphoid collections in the bone marrow of patients known to have a lymphoproliferative disorder are thought to represent either invasion of the marrow by the disease or its site of origin. ${ }^{347}$ Lymphoid aggregates that are both cytologically and morphologically benign are also seen in these patients.'

Patients without known lymphoproliferative disease may also have morphologically benign lymphoid aggregates in their bone marrow. Many workers

Accepted for publication 3 March 1988 consider these to be a normal or physiological finding with no particular disease association when they occur as small, single clusters of mature lymphocytes in a marrow biopsy specimen. ${ }^{189}$ When aggregates are large or numerous, some use the term nodular lymphoid hyperplasia and describe an association with autoimmune disease. ${ }^{18}$ The precise association between nodular lymphoid hyperplasia and lymphoproliferative disease remains unclear. ${ }^{1479}$ From observations on our own clinical material it seemed that some patients with morphologically benign lymphoid aggregates in their bone marrow were later diagnosed as having lymphoproliferative disease.

Published studies on morphologically benign lymphoid aggregates have included at most only limited follow up of patients to assess their eventual diagnosis, even though the time taken to develop full clinical manifestations of some lymphocytic lymphomas and chronic lymphocytic leukaemia may be extensive. ${ }^{1348}$ This paper reports follow up on hospital patients whose marrow biopsy specimens contained lymphoid aggregates. Their eventual diagnoses were compared with those of control patients to assess the practical importance of finding a morphologically benign lymphoid aggregate in a bone marrow biopsy specimen. 


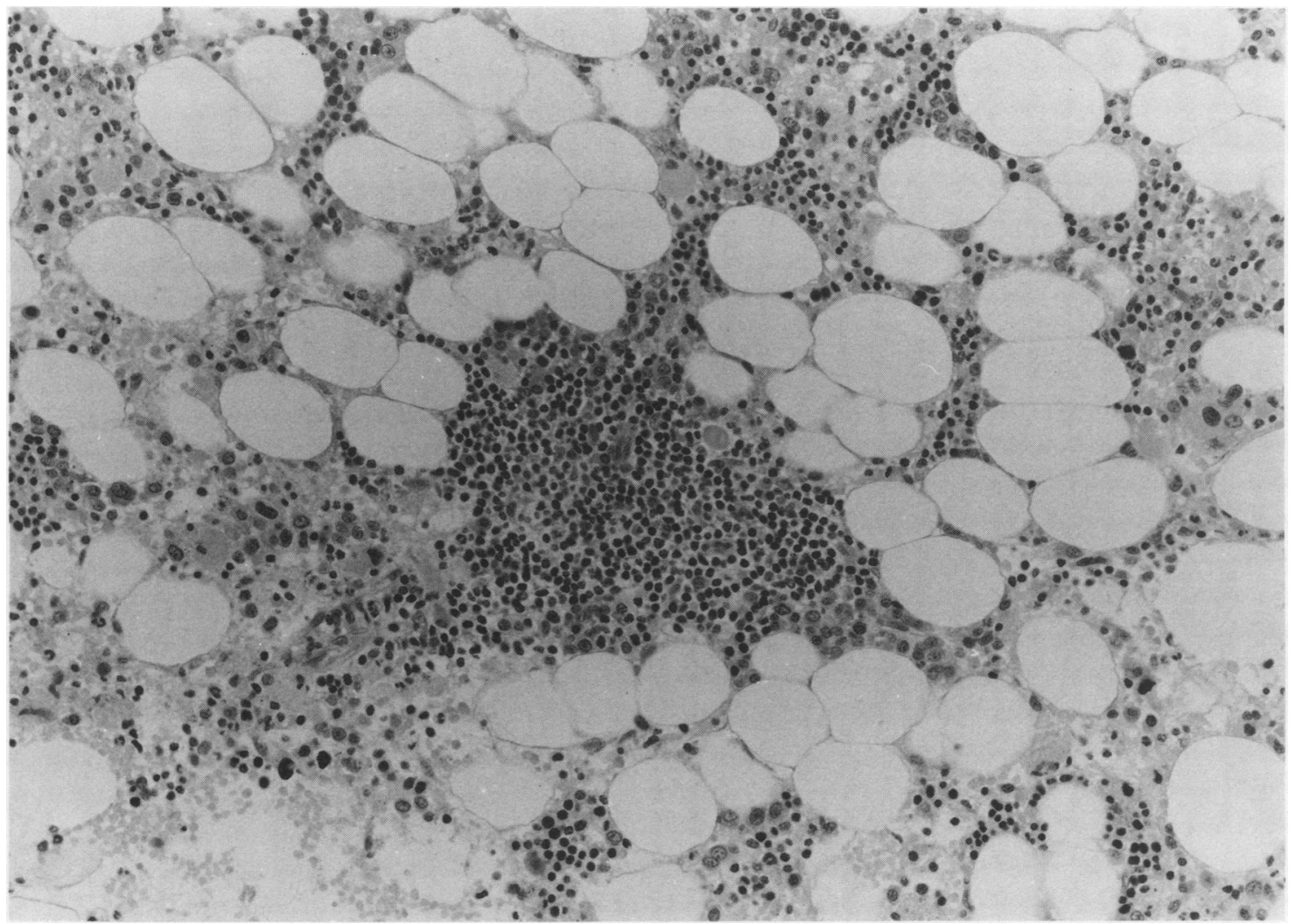

Fig 1 Morphologically benign lymphoid aggregate in trephine biopsy specimen of bone marrow.

\section{Patients and methods}

During the seven years between 1979 and 1985, 786 consecutive patients had 926 iliac crest trephine biopsies and 25 iliac crest bone biopsies performed. These were studied retrospectively. Of these, 430 patients from whom 519 trephine biopsy specimens were taken had confirmed lymphoproliferative disorders at the time of biopsy and were excluded from further study. The remaining 432 biopsy specimens from 356 patients were screened for the presence of lymphoid aggregates. These were identified using light microscopy and conventional stains. Five patients also had $\kappa$ and $\lambda$ light chain immunoperoxidase stains performed. Aggregates were subdivided into three categories: morphologically benign; suspicious - that is, cytologically normal but increased in size or number, or both; and cytologically and morphologically malignant (figs 1-3). ${ }^{28}$

All patients with at least one lymphoid aggregate in their trephine biopsy specimen (aggregate group) were matched by sex and age to within five years with patients whose trephine or bone biopsy specimens did not contain lymphoid aggregates (control group). Case notes were obtained for 84 of the 86 aggregate group patients and 81 of the 86 control group patients. Limited follow up data were available on the seven patients whose notes could not be traced. A standardised data sheet was completed for each patient, paying particular attention to the eventual diagnosis and the length of follow up from the time of the first trephine biopsy with a lymphoid aggregate until death or the last entry in clinical notes (fig 4).

A lymphoproliferative disease was considered to be confirmed if the patient was subsequently shown to have such a disease in a biopsy specimen of an organ other than bone marrow, or at necropsy, or if analysis of peripheral blood lymphocyte surface markers showed evidence of a monoclonal proliferation. A lymphoproliferative disease was considered to be possible if the diagnosis was based on clinical grounds without confirmation by biopsy of organs other than bone marrow, or the patient had an isolated paraproteinaemia. ${ }^{10}$ Follow up was calculated in months to the nearest half month.

Trephine biopsy specimens were taken under local 


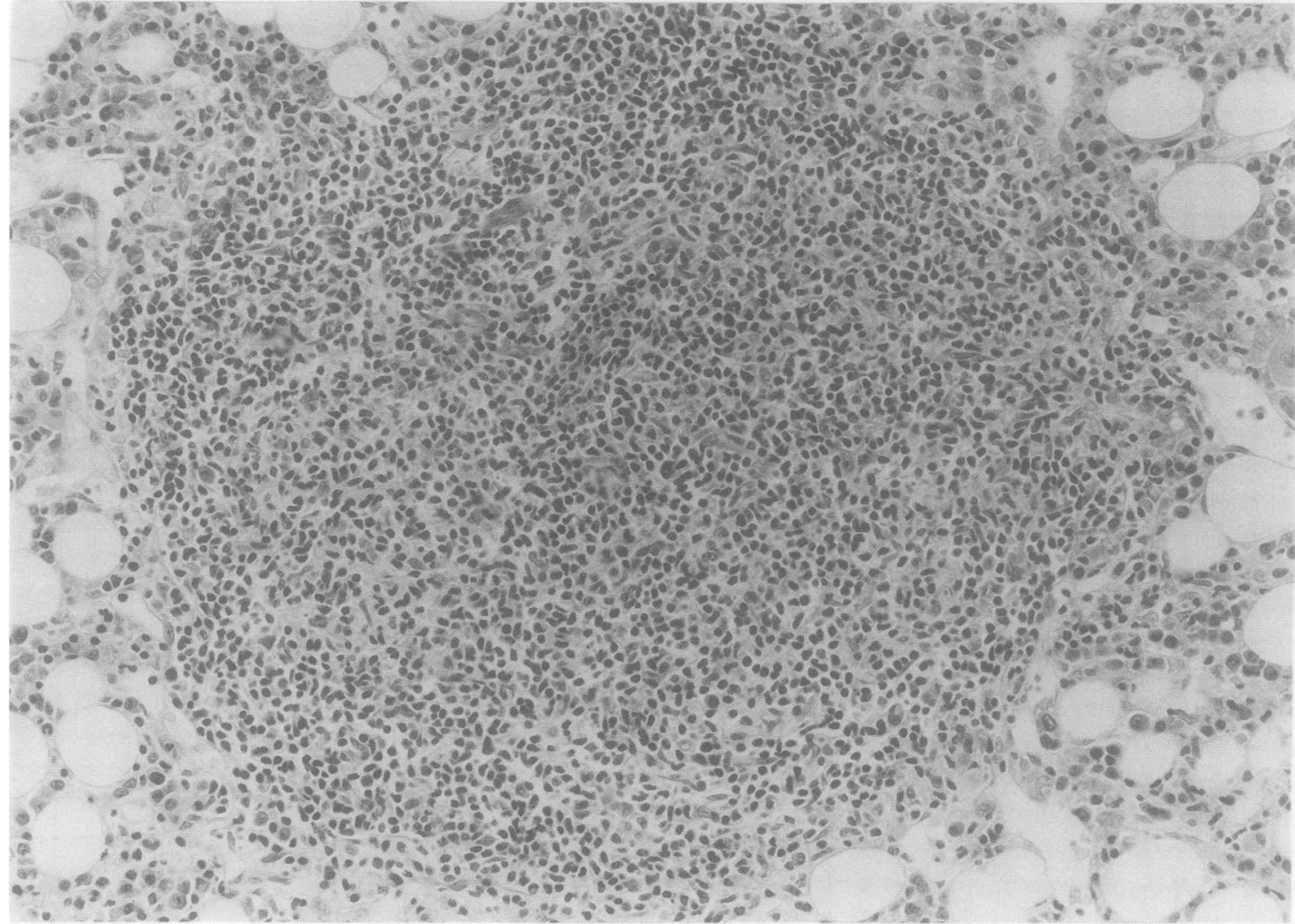

Fig 2 Morphologically suspicious lymphoid aggregate in trephine biopsy specimen of bone marrow. This is larger than the aggregate in fig 1 .

anaesthesia using a Jamshidi needle from the iliac crest. They were fixed in $10 \%$ formol saline containing $5 \%$ acetic acid (v/v) and paraffin wax embedded. Generally, four sections were cut at intervals of 50$100 \mu \mathrm{m}$ and stained with haematoxylin and eosin. Special stains were performed as appropriate.

All 25 bone biopsy specimens were taken from the iliac crest under local anaesthesia. They were then fixed in $10 \%$ formol saline and bisected. One half was decalcified, paraffin wax embedded, and sectioned as above. The other half was styrene embedded without decalcification and sectioned and stained with haematoxylin and eosin and with von Kossa's stain.

The $\chi^{2}$ test with Yates's correction was used to test the significance of differences between aggregate and control group patients.

\section{Results}

One hundred and one trephine biopsy specimens from 86 patients contained at least one lymphoid aggregate. Sixteen of these contained more than one. A germinal centre was seen in a lymphoid aggregate in only one case-a patient with systemic lupus erythematosus. The clinical characteristics of aggregate and control groups are compared in table 1 . In the group without a lymphoid aggregate, including the control patients, there were 270 patients (136 male and 134 female). This sex distribution was not significantly different from that of the group with a lymphoid aggregate. The mean age of the group without a lymphoid aggregate was 51.2 years, with a median of 54 , a range of 14 to 85 , and a standard deviation of $17 \cdot 4$. The ratio of the difference between the means of the two groups to the standard error of the difference of the means was 4.4 , making it unlikely $(p<0.001)$ that the two groups had come from the same population of observations. The group with a lymphoid aggregate was significantly older than the group without a lymphoid aggregate.

The indication for the initial trephine biopsy in the aggregate and control groups is shown in table 2 . In the control group there was a significant excess of bone biopsy specimens $(p<0.05)$. The number of patients whose indication for biopsy was suspected lymphoproliferative disease was significantly higher in the aggregate group $(\mathrm{p}<0.05)$. 


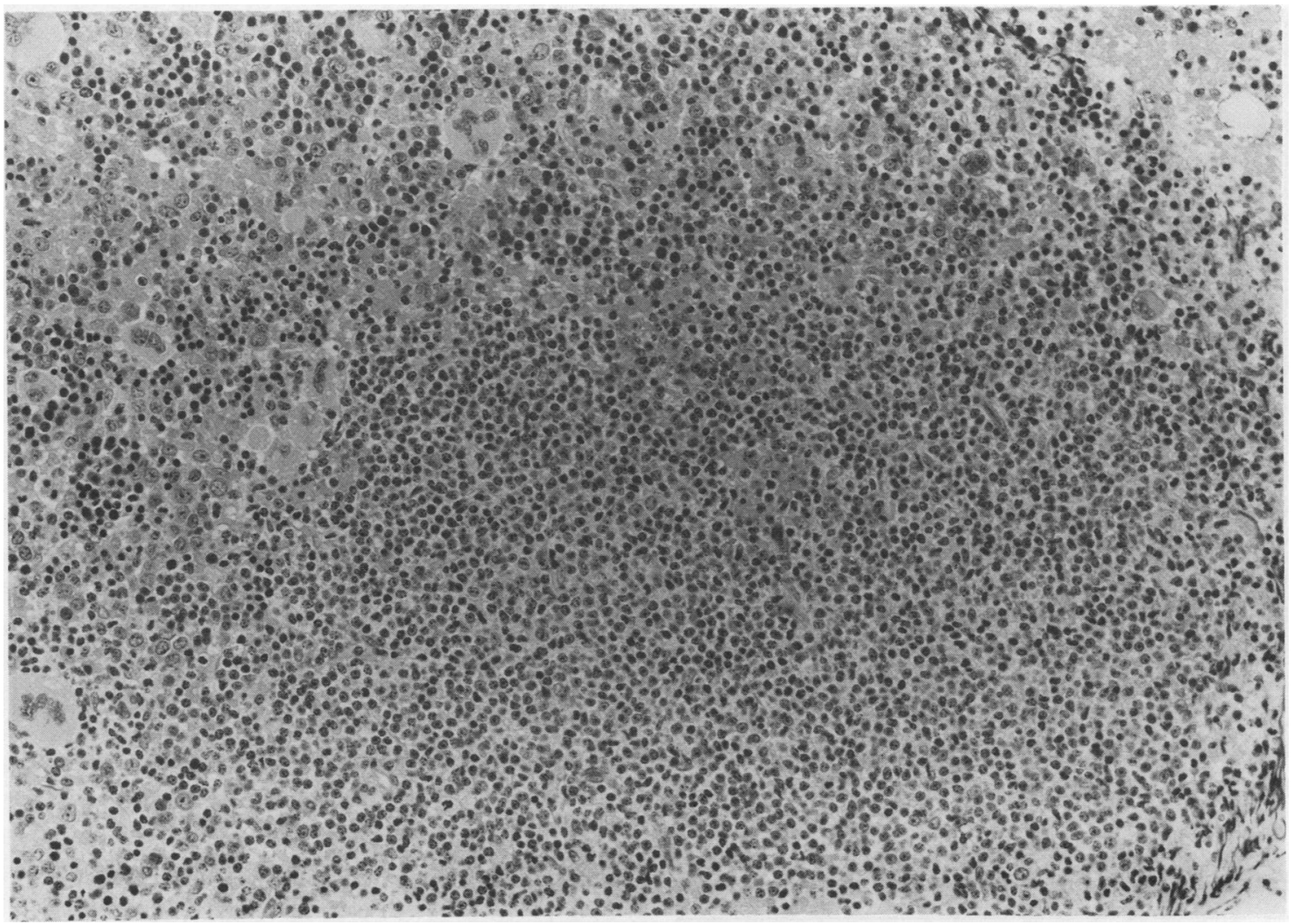

Fig 3 Morphologically malignant lymphoid aggregate in trephine biopsy specimen of bone marrow. This consists of larger cells than those in the aggregates in figs 1 and 2 and its edge is ill defined.

Table 1 Clinical characteristics of aggregate and control groups

\begin{tabular}{|c|c|c|}
\hline & $\begin{array}{l}\text { Aggregate } \\
\text { group }\end{array}$ & $\begin{array}{l}\text { Control } \\
\text { group }\end{array}$ \\
\hline No of patients & $86(45 M, 41 F)$ & $86(45 \mathrm{M}, 41 \mathrm{~F})$ \\
\hline \\
\hline $\begin{array}{l}\text { Mean (median) } \\
\text { Range (SD) }\end{array}$ & $\begin{array}{l}56 \cdot 6(56) \\
27-83(14 \cdot 1)\end{array}$ & $\begin{array}{l}57 \cdot 3(57) \\
27-83(13 \cdot 7)\end{array}$ \\
\hline $\begin{array}{l}\text { Female: } \\
\text { Mean (median) } \\
\text { Range: (SD) }\end{array}$ & $\begin{array}{l}61 \cdot 8(65) \\
30-83(12 \cdot 5)\end{array}$ & $\begin{array}{l}61 \cdot 9(63) \\
34-78(12 \cdot 6)\end{array}$ \\
\hline $\begin{array}{l}\text { All patients: } \\
\text { Mean (median) } \\
\text { Range (SD) }\end{array}$ & $\begin{array}{l}59 \cdot 1(59 \cdot 5) \\
27-83(13 \cdot 5)\end{array}$ & $\begin{array}{l}59 \cdot 5(59 \cdot 5) \\
27-83(13 \cdot 3)\end{array}$ \\
\hline $\begin{array}{l}\text { No of patients dying during } \\
\text { follow up }\end{array}$ & $40(17 \mathrm{M}, 23 \mathrm{~F})$ & $46(25 \mathrm{M}, 21 \mathrm{~F})$ \\
\hline $\begin{array}{l}\text { Length of follow up (months) } \\
\text { Patients known to have died: } \\
\text { Mean (median) } \\
\text { Range (SD) }\end{array}$ & $\begin{array}{ll}12 \cdot 0 & (8) \\
1-57(12 \cdot 5)\end{array}$ & $\begin{array}{c}13 \cdot 9 \quad(4) \\
4 \text { days }-79 \\
(22 \cdot 6)\end{array}$ \\
\hline \multicolumn{3}{|l|}{$\begin{array}{l}\text { Patients alive to end of follow } \\
\text { up: }\end{array}$} \\
\hline $\begin{array}{l}\text { Mean (median) } \\
\text { Range (SD) }\end{array}$ & $\begin{array}{c}21.9(20 \cdot 5) \\
1 \text { day }-70 \cdot 5 \\
(17 \cdot 4)\end{array}$ & $\begin{array}{c}22.9(19 \cdot 5) \\
1 \text { day-72 } \\
(19 \cdot 1)\end{array}$ \\
\hline
\end{tabular}

The eventual diagnoses in both groups are listed in table 3 . There was a highly significant excess of both confirmed and confirmed plus possible lymphoproliferative disease in the aggregate group compared with the controls $(p<0.001)$. Twelve of the 31

Table 2 Indication for initial trephine biopsy

\begin{tabular}{lll}
\hline & $\begin{array}{l}\text { Aggregate } \\
\text { group } \\
(n=86)\end{array}$ & $\begin{array}{l}\text { Control } \\
\text { group } \\
(n=86)\end{array}$ \\
\hline Investigation of: & $23 \mathrm{NS}$ & 18 \\
Abnormal blood count or film & 2 & 1 \\
Systemic symptoms & $31^{*}$ & 18 \\
Suspected lymphoproliferative disease & 6 & 7 \\
$\quad \begin{array}{c}\text { mon-haematological } \\
\text { malignancy }\end{array}$ & 9 & 8 \\
$\quad \begin{array}{c}\text { myeloproliferative disease } \\
\text { acute myelosia }\end{array}$ & 3 & 0 \\
metabolic bone disease & 3 & 4 \\
Others $\quad 0$ & $8 *$ \\
Assessment of known: & 2 & 0 \\
Non-haematological malignancy & 5 & 13 \\
Myeloproliferative disease & 2 & 9 \\
\hline
\end{tabular}

Significant excess: ${ }^{*} p<0.05$. NS $=$ not significant. 


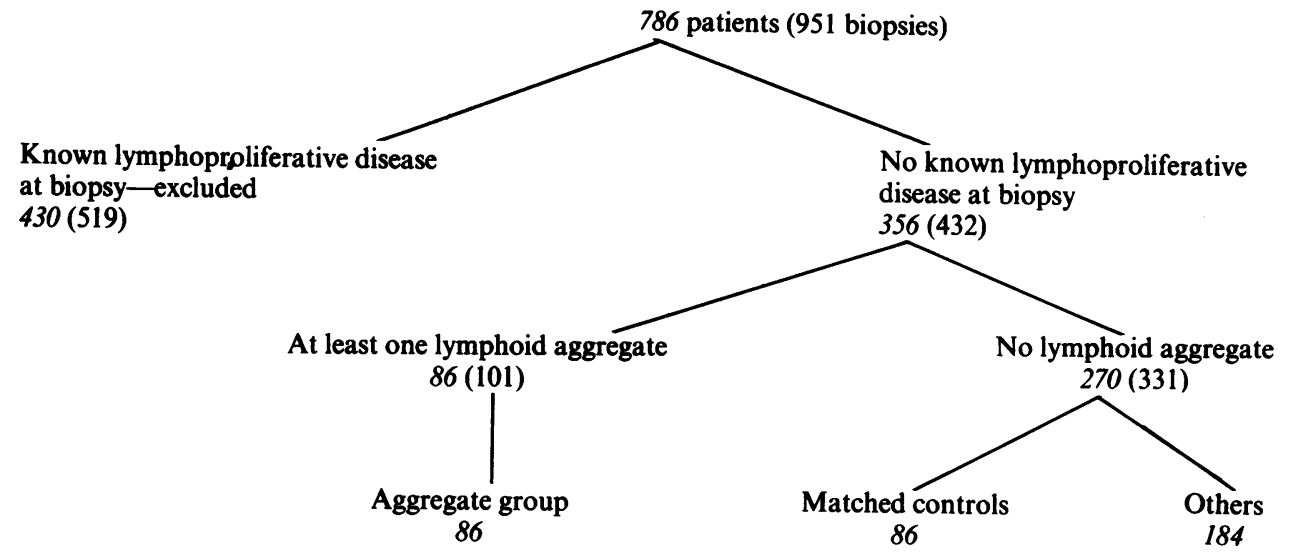

Study group

Fig 4 Design of study.

Table 3 Eventual diagnoses in aggregate and control groups

\begin{tabular}{|c|c|c|}
\hline & $\begin{array}{l}\text { Aggregate } \\
\text { group } \\
(n=86)\end{array}$ & $\begin{array}{l}\text { Control } \\
\text { group } \\
(n=86)\end{array}$ \\
\hline $\begin{array}{l}\text { Proved lymphoproliferative disease* } \\
\text { Possible lymphoproliferative disease } † \\
\text { Non-neoplastic immunological } \\
\text { disorder } \downarrow\end{array}$ & $\left.\begin{array}{l}21 \\
13 \\
11 \mathrm{NS}\end{array}\right\}(\mathrm{p}<0.001)$ & $\begin{array}{l}0 \\
7 \\
5\end{array}$ \\
\hline $\begin{array}{l}\text { Non-haematological malignancy } \\
\text { Disorders of haemopoietic marrow }\end{array}$ & 10 & $23(\mathrm{p}<0.05)$ \\
\hline $\begin{array}{l}\text { Myeloproliferative disease } \\
\text { Myelodysplasia } \\
\text { Acute myeloid leukaemia } \\
\text { Aplasia } \\
\text { Infoction§ } \\
\text { Metabolic bone disease } \\
\text { Others }+\dagger\end{array}$ & $\begin{array}{l}10 \\
6 \\
4 \\
4 \\
7 \\
0 \\
0 \\
0\end{array}$ & $\left.\begin{array}{l}21 \\
5 \\
7 \\
1 \\
1 \\
8 \\
8 \\
8\end{array}\right\}(p<0<0.05)$ \\
\hline
\end{tabular}

* One Hodgkin's disease, 14 low grade, and six high grade nonHodgkin's lymphomas (table 4).

+Clinical diagnosis with no biopsy confirmation in eight aggregate and three control group patients. Paraproteinaemia only present in five aggregate and four control group patients (table 5).

\$ Haematological autoimmune disease in two aggregate and one control group patient: 13 patients had organ specific disease including rheumatoid arthritis $(n=5)$ and polymyalgia rheumatica $(n=3)$.

Tone chemodectoma and one melanoma in the control group. The remaining $\mathbf{3 1}$ had carcinoma, which was present in $\mathbf{1 0}$ of the trephine biopsy specimens.

8Chronic bacterial infection in four aggregate group patients. Viral infection in three aggregate and one control group patient.

††Anaemia of chronic renal failure, malnutrition, unexplained facial swelling, iron deficiency anaemia, mediastinal fibrosis, cerebral vasculitis, hypersplenism secondary to cardiac failure, and myelofibrosis secondary to irradiation. patients in the aggregate group suspected of having a lymphoproliferative disease at biopsy (table 2) were later proved to have one. In nine of these 12 the aggregates were morphologically benign. Another eight of the 31 possibly had a lymphoproliferative disease. Details of the patients with a lymphoid aggregate and subsequently confirmed lymphoproliferative disease are given in table 4. Details of patients with a possible lymphoproliferative disease are given in table 5 .

The mean time between initial bone marrow biopsy and definite confirmation of a lymphoproliferative disease in the 21 patients (table 4) was 3.3 months, range nil (investigations made at the same time as the trephine biopsy) to 28 months. An excess of nonhaematological malignancy was observed in the control group ( $p<0.05)$. Mortalities and mean time to death were similar in the two groups (table 1).

Table 6 shows the relation between the appearance of the lymphoid aggregate in the initial trephine biopsy specimen and the eventual diagnosis. In one biopsy specimen the aggregates were obviously malignant and the patient was shown to have chronic lymphocytic leukaemia. Three biopsy specimens had suspicious aggregates. Of these, two patients were later confirmed to have lymphoproliferative disease, although the aggregate in one biopsy specimen was polyclonal as shown by $\kappa$ and $\lambda$ light chain staining. 
Table 4 Patients with lymphoid aggregate and subsequently confirmed lymphoproliferative disease

\begin{tabular}{|c|c|c|c|c|c|c|c|c|c|c|c|c|c|c|}
\hline Sex & Age & Presentation & $\begin{array}{l}\text { Spleno- } \\
\text { megaly }\end{array}$ & $\begin{array}{l}\text { Hepato } \\
\text { megaly }\end{array}$ & -Lymph- & & $W C C$ & Lymph. & $P t$ & $\begin{array}{l}\text { Marrow- } \\
\text { aspirate }\end{array}$ & $\begin{array}{l}\text { Immuno- } \\
\text { globulins }\end{array}$ & $\begin{array}{l}\text { Lymphocyte } \\
\text { markers }\end{array}$ & $\begin{array}{l}\text { Method of } \\
\text { definitive } \\
\text { diagnosis }\end{array}$ & $\begin{array}{l}\text { Time of } \\
\text { follow-up }\end{array}$ \\
\hline \multicolumn{15}{|c|}{ High grade non-Hodgkin's lymphoma $(n=6)$ : } \\
\hline $\begin{array}{l}\mathbf{M} \\
\mathbf{M}\end{array}$ & $\begin{array}{l}46 \\
47\end{array}$ & $\begin{array}{l}\text { Coeliac disease } \\
\text { Lump in neck }\end{array}$ & $\begin{array}{l}\text { Yes } \\
\text { No }\end{array}$ & $\begin{array}{l}\text { Yes } \\
\text { No }\end{array}$ & $\begin{array}{l}\text { Yes } \\
\text { Yes }\end{array}$ & $\begin{array}{l}12 \cdot 0 \\
12 \cdot 1\end{array}$ & $\begin{array}{l}7 \cdot 0 \\
3 \cdot 3\end{array}$ & $\stackrel{?}{1.06}$ & $\begin{array}{l}202 \\
204\end{array}$ & $\underset{\text { seen }}{\stackrel{?}{\text { Lymphoblasts }}}$ & $\begin{array}{l}\text { Normal } \\
\text { Monoclonal } \\
\lambda \text { chains }\end{array}$ & $\begin{array}{l}\text { Normal } \\
\text { B cell } \\
\text { leukaemia }\end{array}$ & $\begin{array}{l}\text { pm } \\
\text { Node biopsy, } \\
\text { markers, pm }\end{array}$ & $\begin{array}{l}2 y 4 m(D) \\
1 y(D)\end{array}$ \\
\hline $\mathbf{M}$ & 54 & $\begin{array}{l}\text { Lump on } \\
\text { shoulder }\end{array}$ & No & No & No & $14 \cdot 3$ & $5 \cdot 5$ & $1 \cdot 27$ & 443 & Normal & Hypo $\gamma$ glob & Normal & Biopsy of mass & ly8m(A) \\
\hline $\mathbf{M}$ & 58 & $\begin{array}{l}\text { Abdominal } \\
\text { pain }\end{array}$ & No & No & Yes & $14 \cdot 5$ & $13 \cdot 1$ & $2 \cdot 23$ & 406 & Normal & Normal & Normal & Gastric biopsy & $4 m(D)$ \\
\hline $\mathbf{F}$ & 65 & Pancytopenia & Yes & Yes & Yes & $9 \cdot 1$ & $3 \cdot 0$ & 0.7 & 50 & $\begin{array}{l}\text { Iron } \\
\text { deficiency }\end{array}$ & Hypo $\gamma$ glob & Lymphopenia & $\begin{array}{l}\text { Node biopsy, } \\
\text { pm }\end{array}$ & $2 \mathrm{~m}(\mathrm{D})$ \\
\hline $\mathbf{F}$ & 71 & Pancytopenia & Yes & No & No & $8 \cdot 2$ & $2 \cdot 7$ & $1 \cdot 3$ & 153 & Dyserythropoiesis & Hypo $\lambda$ glob & B lymphopenia & $\mathrm{pm}$ & $9 \mathrm{~m}(\mathrm{D})$ \\
\hline $\begin{array}{l}\text { Lov } \\
\mathbf{M}\end{array}$ & $\begin{array}{l}\mathrm{gra} \\
40\end{array}$ & $\begin{array}{l}\text { de non-Hodgkin's } \\
\text { Neutropenia }\end{array}$ & $\begin{array}{l}\text { s lymp } \\
\text { Yes }\end{array}$ & Noma & $\begin{array}{l}=14): \\
\text { Yes }\end{array}$ & $14 \cdot 6$ & $2 \cdot 5$ & 1.59 & 42 & $\uparrow$ Lymphoid cells & Normal & \multirow{2}{*}{ D $\lambda$ B cell clone } & e Markers, pm & lylm(D) \\
\hline $\mathbf{M}$ & 40 & Neuropathy & No & Yes & No & $16 \cdot 5$ & 5.9 & $?$ & 233 & †Lymphoid cells & $\begin{array}{l}\operatorname{IgG} \lambda \\
\text { paraprot }\end{array}$ & & Markers & $5 \mathrm{y} 11 \mathrm{~m}(\mathrm{~A})$ \\
\hline $\begin{array}{l}\mathbf{M} \\
\mathbf{M}\end{array}$ & $\begin{array}{l}52 \\
55\end{array}$ & $\begin{array}{l}\text { Neutropenia } \\
\text { Known glioma }\end{array}$ & $\begin{array}{l}\text { No } \\
\text { No }\end{array}$ & $\begin{array}{l}\text { No } \\
\text { No }\end{array}$ & $\begin{array}{l}\text { No } \\
\text { No }\end{array}$ & $\begin{array}{l}15.0 \\
15.0\end{array}$ & $\begin{array}{r}2 \cdot 4 \\
17 \cdot 3\end{array}$ & $\begin{array}{l}1 \cdot 6 \\
9 \cdot 52\end{array}$ & $\begin{array}{l}136 \\
131\end{array}$ & $\begin{array}{l}\text { †Lymphoid cells } \\
\uparrow \text { Lymphoid cells }\end{array}$ & $\begin{array}{l}\downarrow \text { IgM, IgA } \\
\text { Hypo } \gamma \text { glob }\end{array}$ & $\begin{array}{l}\text { G } \boldsymbol{\kappa} \text { B cell clone } \\
\text { B cell } \\
\text { leukaemia }\end{array}$ & $\begin{array}{l}\text { Markers } \\
\text { Node biopsy, } \\
\text { markers }\end{array}$ & $\begin{array}{l}4 y 5 m(A) \\
2 y 1 m(D)\end{array}$ \\
\hline $\mathbf{M}$ & 56 & Neutropenia & Yes & Yes & Yes & $9 \cdot 9$ & $4 \cdot 2$ & $3 \cdot 14$ & 136 & $\uparrow$ Lymphoid cells & Hypo $\gamma$ glob & $\begin{array}{l}\text { B cell } \\
\text { leukaemia }\end{array}$ & $\begin{array}{l}\text { Node biopsy, } \\
\text { markers, pm }\end{array}$ & lylm(D) \\
\hline $\mathbf{F}$ & 65 & $\begin{array}{l}\text { Fever, weight } \\
\text { loss }\end{array}$ & Yes & No & Yes & $9 \cdot 4$ & $1 \cdot 4$ & $0 \cdot 7$ & 275 & $\downarrow$ Granulopoiesis & Normal & $\begin{array}{l}\mathrm{B} \text { and } \mathrm{T} \\
\text { lymphopenia }\end{array}$ & Node biopsy & $3 \mathrm{y} 5 \mathrm{~m}(\mathrm{~A})$ \\
\hline $\mathbf{F}$ & 67 & $\begin{array}{l}\text { Fever, weight } \\
\text { loss }\end{array}$ & No & No & Yes & $7 \cdot 6$ & $6 \cdot 2$ & $0 \cdot 25$ & 184 & $\uparrow$ Lymphoid cells & Polyclonal $\uparrow$ & B lymphopenia & Node biopsy & $2 m(D)$ \\
\hline $\mathbf{F}$ & 69 & $\begin{array}{c}\text { Haemolytic } \\
\text { anaemia }\end{array}$ & No & Yes & No & 11.9 & $5 \cdot 8$ & $0 \cdot 64$ & 235 & $\uparrow$ Erythropoiesis & Polyclonal $\uparrow$ & $\begin{array}{l}\text { B and T } \\
\text { lymphopenia }\end{array}$ & pm & $\operatorname{lm}(\mathrm{D})$ \\
\hline $\mathbf{F}$ & 72 & $\begin{array}{l}\text { Multiple } \\
\text { sclerosis }\end{array}$ & Yes & No & No & $12 \cdot 3$ & $2 \cdot 2$ & $0 \cdot 4$ & 102 & $\begin{array}{l}\text { Few atypical } \\
\text { lymphocytes }\end{array}$ & $?$ & $?$ & Splenectomy & $2 \mathrm{y} 4 \mathrm{~m}(\mathrm{~A})$ \\
\hline $\mathbf{F}$ & 73 & $\begin{array}{l}\text { Fever, weight } \\
\text { loss }\end{array}$ & Yes & Yes & Yes & $10 \cdot 7$ & 3.9 & $2 \cdot 1$ & 155 & $\uparrow$ Lymphoid cells & $\begin{array}{l}\text { IgM } \kappa \\
\text { paraprot }\end{array}$ & $\begin{array}{l}\text { M } \kappa \text { B cell } \\
\text { clone }\end{array}$ & $\begin{array}{c}\text { Node biopsy, } \\
\text { markers }\end{array}$ & 3y9m(D) \\
\hline $\mathbf{M}$ & 74 & Depression & No & No & No & $13 \cdot 8$ & $4 \cdot 9$ & $?$ & 200 & $?$ & $\begin{array}{l}\operatorname{IgG} \kappa \\
\text { paraprot }\end{array}$ & T lymphopenia & $\mathrm{pm}$ & $1 \mathrm{~m}(\mathrm{D})$ \\
\hline $\mathbf{F}$ & 75 & $\begin{array}{l}\text { Rheumatoid } \\
\text { arthritis }\end{array}$ & No & Yes & No & $9 \cdot 7$ & $8 \cdot 3$ & $6 \cdot 39$ & 111 & †Lymphoid cells & $\underset{\text { paraprot }}{\operatorname{IgG} \kappa}$ & $\begin{array}{l}\mathrm{G} \kappa \mathrm{B} \text { cell } \\
\text { clone }\end{array}$ & Markers & $2 \mathrm{~m}(\mathrm{D})$ \\
\hline $\mathbf{F}$ & 76 & $\begin{array}{l}\text { Fever, weight } \\
\text { loss }\end{array}$ & Yes & Yes & Yes & $13 \cdot 4$ & $3 \cdot 6$ & $1 \cdot 6$ & $?$ & Dyserythropoiesis & Normal & $\begin{array}{l}\text { Hairy cell } \\
\text { leukaemia }\end{array}$ & Markers & $1 \mathrm{y} 9 \mathrm{~m}(\mathrm{D})$ \\
\hline $\mathbf{F}$ & 83 & $\begin{array}{c}\text { Abdominal } \\
\text { pain }\end{array}$ & Yes & Yes & No & $11 \cdot 6$ & $7 \cdot 1$ & $?$ & 434 & $?$ & Normal & $\begin{array}{c}\text { Abnormal } \kappa: \lambda \\
\text { B cell ratio }\end{array}$ & Liver biopsy & $4 \mathrm{~m}(\mathrm{D})$ \\
\hline $\begin{array}{l}\text { Hod } \\
F\end{array}$ & $\begin{array}{l}\text { dgkin' } \\
72\end{array}$ & $\begin{array}{l}\text { s disease }(n=1) \\
\text { Pancytopenia }\end{array}$ & ): Yes & Yes & No & $4 \cdot 7$ & 1.7 & $?$ & 76 & $\uparrow$ Cellularity & $?$ & $?$ & Splenectomy & $1 y(D)$ \\
\hline
\end{tabular}

NOTES: Hb, haemoglobin (g/d); WCC, white cell count ( $\left.\times 10^{9} / 1\right)$; Lymph., lymphocyte count $\left(\times 10^{9} / \mathrm{l}\right)$; Pt, platelet count $\left(\times 10^{9} / \mathrm{l}\right) ; ?$ either not done or result not available; pm, diagnosis made or confirmed at necropsy; D, dead; A, alive; hypo $\gamma$ glob, hypogammaglobulinaemia; paraprot, paraproteinaemia.

The third patient possibly had lymphoproliferative disease.

Eighty two biopsy specimens contained morphologically benign lymphoid aggregates. Eighteen of these patients subsequently had a confirmed lymphoproliferative disease, and in 12 it was a possibility. When only patients with morphologically benign lymphoid aggregates were considered, there was an excess of proved lymphoproliferative disease over their controls. The risk was $18 / 82(22 \%)$ and this was highly significant $(p<0.001)$. No features of the lymphoid aggregates were different between those patients in this group who developed a lymphoproliferative disease and those who did not.

\section{Discussion}

The aim of this study was to assess the diagnostic importance of morphologically benign lymphoid aggregates in bone marrow biopsy specimens. We did this by determining eventual diagnosis in a group of hospital patients whose biopsy specimens contained such aggregates. Compared with a matched control group, these patients had a highly significant excess risk of being found to have a lymphoproliferative disease, in particular non-Hodgkin's lymphoma.

Without a control group we would not have known that the eventual diagnoses on the aggregate group were different from those on the whole population biopsied. It was also necessary to have control patients closely matched by age in particular, as the whole group without a lymphoid aggregate was significantly younger than the aggregate group. Without close matching we would not have known whether any difference in eventual outcome between the groups was due to age alone rather than to factors related to 
Table 5 Patients with possible lymphoproliferative disease

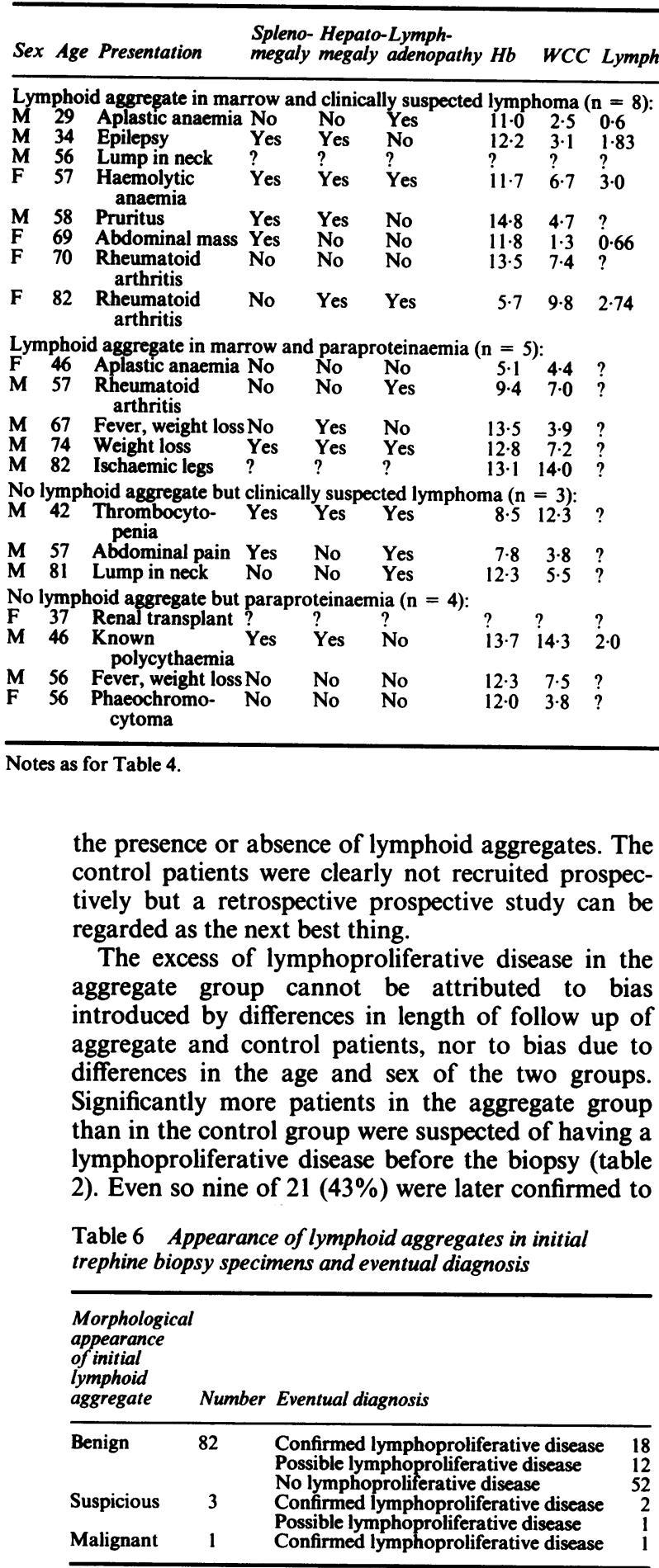

have lymphoproliferative disease and five of $13(38 \%)$ with a possible lymphoproliferative disease were not suspected of this before the biopsy.

Our results are not comparable with those of necropsy studies and may not be applicable to the general population. They are contrary to the findings of biopsy studies in which there is reported to be no particular association of morphologically benign lymphoid aggregates with lymphoproliferative disease. One difference between our study and others is that we followed up the patients for some time after the trephine biopsy so that lymphoproliferative disease developing late after the biopsy specimens were taken was not missed. ${ }^{14911}$

Another difference between our study and others is that we studied marrow from only one site-the iliac crest. Some, for instance, have combined findings from the sternum and iliac crest, "' although there is known to be wide variation in the occurrence of lymphoid aggregates in different parts of the skeleton. Aggregates were common in the sternum but rare in the ileum in a necropsy study. ${ }^{2}$ In addition, some studies have been of concentrated particles of marrow obtained by aspiration. ${ }^{1811}$ Findings on this material may not be comparable with those on trephine biopsy specimens processed in the conventional way.
Time of follow- $u$ $\mathrm{y} 9 \mathrm{~m}(\mathrm{D} \overline{9}$

$y(A)$ क

y(A)

$5 y 7 m(A \stackrel{0}{9}$

(D)

(A)

y4m(A)

m(A)

$2 \mathrm{y} 2 \mathrm{~m}(\mathrm{~A})$

$2 y(A)$ హ)

y3m(ADO

m(D) 윽

m(D) $\subseteq$

ylm(Dर́

(A) $\overrightarrow{0}$

y6m(ADO 
One explanation of our findings is that patients developing a lymphoproliferative disease have a higher number and density of morphologically benign lymphoid aggregates than patients with other conditions. The likelihood of obtaining an aggregate in a random trephine biopsy specimen is therefore higher. Concentrations of marrow samples and a biopsy specimen of the sternum are likely to increase the total yield of lymphoid aggregates in all patients and may obscure the clear association seen in this study between lymphoid aggregates in the iliac crest and lymphoproliferative diseases.

We cannot settle the question of whether such aggregates are truly benign and reactive or are neoplastic. In most other conditions in which they are found, such as infections, autoimmune diseases, or carcinomas (table 3 ) it is likely that these aggregates are reactive. ${ }^{12}$ In disorders of the haemopoietic marrow, however, the aggregates may indicate neoplastic proliferation of lymphocytes derived from the same stem cells as the haemopoietic cells. ${ }^{1314}$

The practical importance of our results is that morphologically benign lymphoid aggregates should not be ignored in iliac crest biopsy specimens from patients not known to have a lymphoproliferative disorder. Such a finding indicates that the patient has a significant risk of being found to have a lymphoproliferative disease. Indeed, when patients are discounted whose marrow biopsy specimens indicate another definite diagnosis such as metastatic carcinoma or myeloproliferative disorder, there is a higher probability that a lymphoproliferative disorder will eventually be diagnosed.

We are grateful to Professor J Stuart for permission to study his patients and for criticism of the manuscript; to Mrs CA Roginski and Mrs S Wilson, West Midlands Regional Cancer Registry, for follow up information; to Mrs CJ Sparke for the photographic prints; and to Miss AJ Wright for typing the manuscript.

\section{References}

1 Rywlin AM, Ortega RS, Dominguez CJ. Lymphoid nodules of bone marrow: normal and abnormal. Blood 1974;43:389-400.

2 Hashimoto $\mathbf{M}$, Higuchi $\mathbf{M}$, Saito $T$. Lymph nodules in human bone marrow. Acta Pathol Japan 1957;7:33-52.

3 Bartl R, Frisch B, Burkhardt R, Jager K, Pappenberger R, Hoffmann-Fezer G. Lymphoproliferations in the bone marrow: identification and evolution, classification and staging. J Clin Pathol 1984;37:233-54.

4 Krause JR. Lymphoproliferative disorders. In: Krause JR, ed. Bone marrow biopsy. New York: Churchill Livingstone, 1981:109-43.

5 Warnke R, Pederson M, Williams C, Levy R. A study of lymphoproliferative diseases comparing immunofluorescence with immunohistochemistry. Am J Clin Pathol 1978;70:867-75.

6 Sangster G, Crocker J, Nar P, Leyland MJ. Benign and malignant (B cell) focal lymphoid aggregates in bone marrow trephines shown by means of an immunogold-silver technique. J Clin Pathol 1986;39:453-7.

7 Burkhardt R, Frisch B, Bartl R. Bone biopsy in haematological disorders. J Clin Pathol 1982;35:257-84.

8 Rywlin AM. Histopathology of the bone marrow. Boston: Little, Brown, 1976:95-132.

9 Navone R, Valpreda M, Pich A. Lymphoid nodules and nodular lymphoid hyperplasia in bone marrow biopsies. Acta Haematol 1985;74:19-22.

10 Carter A, Tatarsky I. The physiopathological significance of benign monoclonal gammopathy: a study of 64 cases. $\mathrm{Br} J$ Haematol 1980;46:565-74.

11 Maeda K, Hyun BH, Rebbuck JW. Lymphoid follicles in bone marrow aspirates. Am J Clin Pathol 1977;67:41-8.

12 Frisch B, Lewis SM, Burkhardt R, Bartl R. Biopsy pathology of bone and bone marrow. London: Chapman and Hall Medical, 1985:180-230.

13 Brown G, Bunce CM, Howie AJ, Lord JM. Stochastic or ordered lineage commitment during hemopoiesis? Leukemia 1987;1:150-3.

14 Rose PE, Howie AJ, Galvin GP, Bunce CM, Brown G. Lineage determination during haemopoiesis and classification of myelodysplastic disorders. B J Haematol 1986;64:626-8.

Requests for reprints to: Dr AJ Howie, Department of Pathology, The Medical School, University of Birmingham, Edgbaston, Birmingham B15 2TJ. 